\title{
Association between calcium intake, parathormone levels and blood pressure during pregnancy*
}

\author{
Aníbal Nieto, MD, PhD¹, Julián A. Herrera, MD², José Villar, MD³, \\ Roberto Matorras, MD, $\mathrm{PhD}^{4}$, Carlos López de la Manzanara, MD, $\mathrm{PhD}^{1}$, \\ Ignacio Arribas, MD, PhD ${ }^{5}$, Julia Álvarez, MD, PhD ${ }^{6}$, Eugenia Peiró, MD, PhD ${ }^{5}$
}

\section{SUMMARY}

Purpose: To evaluate the association between calcium intake from diet, calciotropic hormones (PTH, PTH-rp), vasoactive regulators (endothelin, nitric oxide) and blood pressure levels during pregnancy, birth and puerperium.

Method: In a prospective study 149 healthy normotensive primigravidas were followed-up from 15 weeks of gestation to puerperium. Daily calcium intake, calciuria, PTH, PTH-rp, endothelin, nitrite-nitrate, and Holter Test were assessed. Linear regression models were performed to evaluate the association between calcium intake, blood pressure levels and the laboratory tests. Multivariate regression models were performed to control potential confounders.

Results: A significant increase of calcium intake during pregnancy was observed $(931 \pm 301 \mathrm{mg} /$ day to $1,195 \pm 467 \mathrm{mg} /$ day, $\mathrm{p}<0.001)$. Plasma PTH-rp, endothelin, and nitrite-nitrate levels did not change during pregnancy. Among the women $38(25.4 \%)$ had low calcium intake $(<800 \mathrm{mg} /$ day $)$ with a larger increase of systolic and diastolic blood pressure during pregnancy $(\mathrm{p}=0.04)$ birth $(\mathrm{p}=0.006)$ and puerperium $(\mathrm{p}=0.01)$. After adjusting for other factors the multivariate analyses showed statistical association between low calcium intake, high parathormone levels and high systolic blood pressure levels during pregnancy $(\mathrm{p}=0.002)$.

Conclusion: Low calcium intake during pregnancy is associated with a larger increase of systolic blood pressure and high parathormone levels.

Keywords: Calcium intake; Endothelin; PTH: PTH-rp: Preeclampsia; Nitric oxide.

\section{Asociación entre consumo de calcio, niveles de parathormona y presión arterial en el embarazo}

\section{RESUMEN}

Objetivo: Evaluar la asociación entre la ingesta de calcio en el embarazo, los niveles de presión arterial, las hormonas calciotrópicas (PTH, PTH-rp) y sustancias vasorreguladoras (endotelina, óxido nítrico).

Métodos: Se realizó un estudio prospectivo con 149 primigrávidas normotensas que fueron incluidas en la semana 15 de gestación con seguimiento y evaluación hasta el puerperio. Se evaluó la ingesta diaria de calcio, la monitoría Holter de 24 horas, la calciuria, PTH, PTH-rp, la endotelina, nitritos y nitratos. Se siguieron modelos de regresión lineal para evaluar la asociación entre la ingesta de calcio, la presión arterial, las hormonas calciotrópicas y los vasorreguladores. Para controlar las variables

* This study was financially supported by the Ministry of Health of Spain (Grant FIS No PI 021320), Madrid. Preliminary results were presented as an abstract at the World Congress of Obstetrics and Gynecology (FIGO), Kuala Lumpur, Malaysia, November 2006.

1. Associate Professor, Department of Obstetrics and Gynaecology, Hospital Universitario Príncipe de Asturias, Universidad de Alcalá, Alcalá de Henares, Madrid, España. e-mail: anibal.nieto@uah.es clmanzanara@hotmail.com

2. Professor Emeritus, Head Department of Family Medicine, Universidad del Valle, Cali, Colombia. Honorary Professor, Obstetrics \& Gynecology, Universidad de Alcalá, Alcalá de Henares, Madrid, España. e-mail: herreja@univalle.edu.co

3. HRP Research Program,WHO, Geneva, Switzerland. e-mail: villarj@who.int

4. Assistant Professor, Department of Obstetrics and Gynecology, Hospital de Cruces, Universidad del País Vasco, Bilbao, España.e-mail: roberto.matorras@osakidetza.net

5. Clinical Analysis Department, Hospital Universitario Príncipe de Asturias, Universidad de Alcalá, Alcalá de Henares, Madrid, España.

6. Department of Obstetrics and Gynecology, Hospital Príncipe de Asturias, Alcalá de Henares, Madrid, España. Received for publication June 19, 2008 Accepted for publication April 14, 2009 
de confusión se hicieron modelos de regresión múltiple.

Resultados: Durante el embarazo la ingesta de calcio aumentó significativamente $(931 \pm 301 \mathrm{mg} /$ día a $1,195 \pm 467 \mathrm{mg} /$ día, $\mathrm{p}<0.001)$. Entre las embarazadas $38(25.4 \%)$ tuvieron una baja ingesta de calcio ( $<800 \mathrm{mg} /$ día $)$ asociada con mayores niveles de presión arterial sistólica y diastólica durante el embarazo $(p=0.04)$, en el parto $(p=0.006)$ y en el puerperio $(\mathrm{p}=0.01)$. Los mayores niveles de presión arterial sistólica durante el embarazo se asociaron con mayores niveles de paratormona y con menores niveles de ingesta de calcio $(\mathrm{p}=0.002)$. Los niveles plasmáticos de PTH-rp, endotelina, nitritos y nitratos no mostraron cambios durante el embarazo.

Conclusión: La baja ingesta de calcio en el embarazo se asoció con mayores niveles de paratormona y de presión arterial sistólica durante el embarazo.

Palabras clave: Ingesta de calcio; Endotelina; PTH; PTH-rp; Preeclampsia; Óxido nítrico.

Preeclampsia is the first cause of maternal morbidity, mortality and intrauterine growth restriction (IUGR) ${ }^{1}$. In developing countries, a high proportion of the pregnant women have IUGR associated with unexplained medical factors ${ }^{1}$. Slight elevation of blood pressure, although within clinical normotensive range, can alter uterine and placental perfusion and influence fetal growth ${ }^{2}$. A high calcium diet enhances vasodilation and reduces blood pressure in experimental hypertension ${ }^{3,4}$ with suppresion of the parathyroid hypertensive factor ${ }^{5}$. A low calcium diet enhances vasoconstriction and increases PTH and coronary artery disease ${ }^{6}$. Low calcium intake increases the incidence of eclampsia and the supplementation in high risk pregnant women can reduce preeclampsia complications ${ }^{7}$. In non-pregnant women high levels of serum PTH were associated with markedlly increased blood pressure ${ }^{8}$. Jesspersen et al. ${ }^{9}$ suggested a role of serum PTH on the regulation of blood pressure in pregnant women. Jorde et $a .^{2}$ reported an association between low calcium intake, parathyroid hormone, and blood pressure during pregnancy. The association between calcium intake, calciotropic hormones and blood pressure during the pregnancy, birth and puerperium is not well studied. In an attemp to corroborate and to extend conclusions from previous studies $^{2}$ results from a prospective study of the blood pressure levels during pregnancy, birth, and puerperium as well as the relationship with calcium intake from diet, calciotropic hormones and vasoactive regulators for gaining a better understanding of the pathophysiologic mechanisms are here reported.

This study was approved by the Human Ethical Committee of Universidad of Alcalá, Spain and Hospital Príncipe de Asturias, Alcalá. All recruited pregnant women were informed about general objectives of the study and the informed consent was read and signed by all recruited pregnant patients.

\section{METHODS}

A prospective study was performed from 15 weeks of gestational age to puerperium period (at least 48 hours). All Spanish healthy primigravid women during 2005-2006 were screened and recruited in the Hospital Universitario Príncipe de Asturias (Alcalá de Henares, Madrid,España). Inclusion criteria (healthy primigravida, single pregnancy, first prenatal visit at 15 weeks of gestational age) and exclusion criteria (diastolic blood pressure of $85 \mathrm{~mm} \mathrm{Hg}$ or more at the antenatal visit, personal history of hypertension, cardiovascular or renal disease) were verified by a member of the research team. The gestational age was determined according to the date of the last menstrual period if the woman had a regular (26-31) day cycle; otherwise an ultrasound evaluation for the gestational age was performed. The Institutional Human Ethical Committee approved this survey. Eligible women who agreed to participate in the study received verbal information about the research and were requested to sign written informed consent forms.

Upon enrollment, physicians completed a questionnaire including socio-demographic and obstetric characteristics (age, race, residence, education, socioeconomic status, parity). The participants were recruited at the first prenatal visit. The calcium nutritional inventory, 24-hour calciuria, creatinuria and proteinuria; routine clinical and analytical parameters (hemoglobin, hematocrit, creatinine, uric acid) as well as other special parameters, such as calciotropic hormones (PTH, PTH$\mathrm{rp}$ ) and vasoactive regulators (endothelin and nitritenitrate) were evaluated.

A volume of $10 \mathrm{ml}$ of whole peripheral blood was obtained from each individual by venipuncture of the antecubital vein at 15 weeks of gestational age and at 28 weeks of gestational age. Plasma was separated immediately by centrifugation, fractionated into several aliquots, and stored frozen at $-80^{\circ} \mathrm{C}$ until analysis. 
Serum levels of endothelin were determined by immunoradiometric assay (IRMA) (Nichol Institute Diagnostics, San Clemente, CA, USA) ${ }^{10}$ using reagents from Amersham Biosciences (Endothelin 1 ELISA System, Buckinghamshire, UK). PTH, PTH-rp, nitritenitrate serum levels were measured by using sequential immunometric quimioluminiscent in solid phase assay, for two sites (IRMA) ${ }^{11}$ and for Griess reaction after nitrate reduction ${ }^{12}$, respectively. The instruments used were Hitachi analyzer (917 model, Roche Diagnostics, Japan), Immulite Diagnostic 2000 (Dipesa, DPC, Los Angeles, CA, USA), Coulter STKS Analyzer (Coulter Electronics Corporation. Florida, USA) and Colorimetric Analyzer (Alexis Biochemical, San Diego, CA, USA). The lowest detectable concentration for PTH was $1 \mathrm{pg} /$ $\mathrm{ml}$ and for nitrite-nitrate was $2.5 \mu \mathrm{mol} / \mathrm{l}$. For parathormone laboratory tests the coefficients of variation, within- and between- assay, were $6.3 \%$ and $8.8 \%$, respectively.

The calcium nutritional inventory was performed by recording the last week's diet as recomended by $\mathrm{WHO}^{13}$. During 24 hours before the laboratory tests the diet was free of nitrite and nitrate. All clinical and laboratory tests were repeated at 28 weks of gestational age. Blood pressure was verified with a standardized mercurial sphygmomanometer at each prenatal visit (phase $\mathrm{V}$ Korotoff method=diastolic pressure).

The mean values of two consecutive measurements were used for analysis. At 28 weeks of gestational age, blood pressure measurements were obtained via blood pressure Holter test using the Mobil-o-Graph ABP Control Numbed Cardiac Diagnostics (Sheffield, UK) and was interpreted based on the MAPA technique (WHO standardized method with reduced intra-assay variability) ${ }^{14}$ by a blind independent researcher from the Nephrology unit (Hospital Universitario Príncipe de Asturias). All of the patients were followed up and received the standard antenatal visits every month until the $36^{\text {th }}$ week of gestation and twice a month thereafter. Maternal and neonatal complications were evaluated.

The sample size was calculated by convenience as a pilot study to get a better understanding of physiologic mechanisms between blood pressure levels, calcium intake and vasoactive mediators. Means are presented with their standard deviation. Differences between continuous variables were evaluated with the two-tailed $t$ test and Anova for variables that were normally distributed and the Kruskall-Wallis test for variables that were not normally distributed. $\chi^{2}$ or Fischer exact test (if the smallest value was under 5) was used to analyze differences in categorical variables.

To facilitate the statistical analyses the pregnant women were divided into three groups according to their calcium basal intake: low calcium intake $<800 \mathrm{mg}$ /day, normal calcium intake $800-1200 \mathrm{mg} /$ day, and high calcium intake $>1200 \mathrm{mg} /$ day $^{15,16}$. Linear regression models were performed between systolic, diastolic and mean blood pressure (during pregnancy, birth, and puerperium) (dependent variable) and independent variables (basal calcium intake and laboratory tests). Multivariate regression models were performed to control for potential confusion. Correlation coefficients and their 95\% confidence intervals were calculated by using SPSS for Windows statistical package (version 11.5). A $p<0.05$ was regarded as statistically significant.

\section{RESULTS}

A total of 174 healthy primigravid women at 15 weeks of gestational age were screened in two hospital outpatient clinics. Among the screened women, 9 (5.1\%) were excluded for maternal pathology. A total of 16 (9.6\%) patients were lost to follow-up and were excluded from analysis. The final analysis was based on 149 women.

Socioeconomic status of the women evaluated according to the National Department of Statistics (range 1-4) was low (level 1) in 34 women (22.8\%), medium (level 2) in 42 (28.1\%), high (level 3) in 38 $(25.6 \%)$, and very high (level 4$)$ in 35 (23.4\%). All women were literate, Spanish white, and living at the urban area.

Women were on average $28.9 \pm 4.8$ years of age. Body Mass Index (BMI) was $24.3 \pm 4.1$ on average, with obesity (BMI $>30)$ observed in $14(9.4 \%)$ pregnant women. Participants gained a mean of $12.6 \pm 5.4 \mathrm{~kg}$ during pregnancy. A total of 24 (16.1\%) women smoked a median of 5 cigarettes/day (range 2-20). At birth the mean gestational age was $39.1 \pm 1.6$ weeks.

Physiological variations of mean blood pressure throughout pregnancy were observed: $111.8 / 62.3 \pm 11.3$ / $7.2 \mathrm{~mm} \mathrm{Hg}$ at inclusion, $114.2 / 63.4 \pm 10.8 / 7.3 \mathrm{~mm} \mathrm{Hg}$ at 28 weeks, and $117.4 / 66.4 \pm 12.1 / 12.0 \mathrm{~mm}$ at 35 weeks, $120.9 / 69.2 \pm 14.6 / 11.3 \mathrm{~mm}$ at birth, and $115.9 / 65.8 \pm 11.8 /$ 
Table 1

Sociodemographic characteristics and daily basal calcium intake $(n=149)$

\begin{tabular}{|c|c|c|c|c|}
\hline & \multicolumn{3}{|c|}{ Daliy calcium intake } & \multirow[b]{2}{*}{$\mathbf{p}$} \\
\hline & ow $(<800 \mathrm{mg})(\mathrm{n}=38)$ & Normal $(800-1.200 \mathrm{mg})(\mathrm{n}=39)$ & High $(>1.200 \mathrm{mg})(\mathrm{n}=72)$ & \\
\hline \multicolumn{5}{|l|}{ Age } \\
\hline $15-19$ yrs old & $1(2.6)$ & $2(5.1)$ & $2(2.7)$ & \\
\hline $20-35$ yrs old & $36(94.7)$ & $35(89.7)$ & $69(95.8)$ & \\
\hline$>35$ yrs old & $1(2.6)$ & $2(5.1)$ & $1(1.4)$ & 0.94 \\
\hline \multicolumn{5}{|l|}{ Body Mass Index } \\
\hline Malnutrition (<19) & $2(5.2)$ & $3(7.7)$ & $5(6.9)$ & \\
\hline Normal (19-25) & $27(71.0)$ & $26(66.6)$ & $51(70.8)$ & \\
\hline Overweight $(>25-30)$ & $7(18.4)$ & $8(20.5)$ & $12(16.7)$ & \\
\hline Obesity $(>30)$ & $2(5.2)$ & $2(5.1)$ & $4(5.6)$ & 0.78 \\
\hline \multicolumn{5}{|c|}{ Socioeconomic status } \\
\hline Low (Level 1) & $3(7.9)$ & $11(28.2)$ & $11(15.3)$ & \\
\hline Medium (Level 2) & $15(39.5)$ & $10(25.6)$ & $24(33.3)$ & \\
\hline High (Level 3) & $15(39.5)$ & $9(23.0)$ & $24(33.3)$ & \\
\hline Very high (Level 4) & $5(13.1)$ & $9(23.0)$ & 13(18.0) & 0.77 \\
\hline \multicolumn{5}{|l|}{ Educational level } \\
\hline University & $27(71.0)$ & $26(66.6)$ & $51(70.8)$ & 0.91 \\
\hline \multicolumn{5}{|l|}{ Race } \\
\hline Hispanic white & $38(25.4)$ & $39(26.4)$ & $72(48.2)$ & 0.64 \\
\hline
\end{tabular}

Data are presented as proportions $\mathrm{n}(\%)$. Two-tailed t test was used to evaluate differences with normal distribution of data

$9.3 \mathrm{~mm} \mathrm{Hg}$ at puerperium. The mean 24-hour blood pressure (daytime and nightime) reported by the Holter Test at 28 weeks of gestational age was 104.89/ $65.03 \pm 7.98 / 6.14 \mathrm{~mm} \mathrm{Hg}$. At inclusion the sociodemographic characteristics were similar according to the groups of daily calcium intake (low, normal, high) (Table 1). The plasma calcium levels and PTH levels had no differences in accordance with the daily calcium intake groups $(9.6 \pm 0.2 \mathrm{mg}, 9.0 \pm 0.2 \mathrm{mg}, 9.2 \pm 0.3 \mathrm{mg}$, $\mathrm{p}=0.43)(26.9 \pm 13.3 \mathrm{pg} / \mathrm{ml}, 23.1 \pm 12.7 \mathrm{pg} / \mathrm{ml}, 23.4 \pm 13.8$ $\mathrm{pg} / \mathrm{ml}, \mathrm{p}=0.73$ ) respectively. The plasma calcium was positively correlated with the calcium intake $(\mathrm{r}=0.87$, $\mathrm{p}=0.01$ ).

At inclusion high calcium intake (HCI) $(>1.200 \mathrm{mg} /$ day) was observed in $72(48.2 \%)$ pregnant women, normal calcium intake (NCI) (800-1,200 mg/day) in 39 $(26.4 \%)$ and low calcium intake (LCI) $(<800 \mathrm{mg} /$ day $)$ in $38(25.4 \%)$ pregnant women. During the second trimester the calcium intake increased $(930.6 \pm 300.7 \mathrm{mg} /$ day to $1195 \pm 467 \mathrm{mg} /$ day, $\mathrm{p}<0.001$ ) and PTH decreased without changes on PTH-rp, endothelin and nitrite-nitrate levels (Table 2). In all recruited pregnant women the calcium intake was not correlated with systolic blood pressure $(p=0.53)$ nor with diastolic blood pressure $(p=0.57) .24$ hour urine volume and creatinuria increased $(1,811 \pm 741$ $\mathrm{ml}$ to $1,890 \pm 959 \mathrm{ml}, \mathrm{p}<0.01)(1,076 \pm 325 \mathrm{mg}$ to $1,103 \pm$ $280 \mathrm{mg}$ ). In contrast 24 hours calciuria decreased ( $290.3 \pm 134 \mathrm{mg}$ to $280.6 \pm 140 \mathrm{mg}, \mathrm{p}<0.001)$ without differences on 24 hours proteinuria ( $107 \mathrm{mg}$ range $0-600$ to $168 \mathrm{mg}$ range $0-522, \mathrm{p}=0.56$ ).

At third trimester the levels of hemoglobin, hematocrit, creatinine and uric acid were normal and had no differences according to daily calcium intake (Table 3 ). The creatinine clearence was normal in all recruited pregnant women (100.3 \pm 23.3$)$. Creatinine clearance no showed differences according to calcium intake (LCI: $99 \pm 22$, NCI: $102.2 \pm 19$; HCI: $100.3 \pm 23.3$; $\mathrm{p}=0.81$ ).

In the group of women with low calcium intake was observed the largest increase in diastolic blood pressure during pregnancy (LCI median $7.80 \mathrm{~mm} \mathrm{Hg}$, range 3.01- 
Table 2

Parathormone and vasoactive mediators during the pregnancy $(n=149)$

\begin{tabular}{|c|c|c|c|c|}
\hline \multirow[b]{2}{*}{ Laboratory tests } & \multicolumn{4}{|c|}{ Gestational age } \\
\hline & At inclusion & \multicolumn{2}{|c|}{28 weeks } & $\mathbf{p}$ \\
\hline $\mathrm{PTH}(\mathrm{pg} / \mathrm{ml})^{\mathrm{a}}$ & $20.9(4.0-61.0)$ & \multicolumn{2}{|c|}{$18.85(1.0-81.0)$} & 0.03 \\
\hline PTH r-P (pg/ml) $)^{\mathrm{a}}$ & $0.39(0.01-4.34)$ & \multicolumn{2}{|c|}{$0.86(0.01-4.34)$} & 0.11 \\
\hline Endothelin (ET 1, fmol/ I) ${ }^{\mathrm{a}}$ & $1.26(0.01-5.91)$ & \multicolumn{2}{|c|}{$1.78(0.01-6.44)$} & 0.28 \\
\hline \multirow[t]{3}{*}{ Nitrites-nitrates $(\mu \mathrm{mol} / \mathrm{l})^{\mathrm{a}}$} & $10.23(4.77-31.6)$ & \multicolumn{2}{|c|}{$10.99(1.81-58.8)$} & 0.46 \\
\hline & \multicolumn{3}{|c|}{ Daily calcium intake } & \multirow[b]{2}{*}{$\mathbf{p}$} \\
\hline & Low $(n=38)$ & Normal $(n=39)$ & High $(n=72)$ & \\
\hline PTH $(\mathrm{pg} / \mathrm{ml})^{\mathrm{a}}(15 \mathrm{wks}) 26.9 \pm 10$ & $23.1 \pm 9$ & $23.4 \pm 10$ & 0.60 & \\
\hline PTH (pg/mla (28 wks) & $21.2 \pm 9$ & $21.7 \pm 10$ & $21.9 \pm 9$ & 0.84 \\
\hline PTH r-P (pg/ml)a (15 wks) & $11.8 \pm 4$ & $11.3 \pm 5$ & $16.4 \pm 6$ & 0.11 \\
\hline PTH r-P (pg/ml)a (28 wks) & $10.6 \pm 5$ & $8.1 \pm 4$ & $8.7 \pm 3$ & 0.30 \\
\hline Endothelin (ET 1, fmol/ I) ${ }^{\mathrm{a}}$ (15 wks) & $17.2 \pm 7$ & $14.7 \pm 6$ & $21.6 \pm 9$ & 0.35 \\
\hline Endothelin (ET 1, fmol/ I) ${ }^{\mathrm{a}}$ (28 wks) & $12.0 \pm 5$ & $13.5 \pm 6$ & $15.4 \pm 7$ & 0.70 \\
\hline Nitrites-nitrates $(\mu \mathrm{mol} / \mathrm{l})^{\mathrm{a}}(15 \mathrm{wks})^{\mathrm{b}}$ & $10.3 \pm 2.8$ & $9.9 \pm 4.2$ & $11.1 \pm 5.2$ & 0.72 \\
\hline Nitrites-nitrates $(\mu \mathrm{mol} / \mathrm{l})^{\mathrm{a}}(28 \mathrm{wks})^{\mathrm{b}}$ & $10.4 \pm 4.2$ & $13.0 \pm 6.4$ & $11.9 \pm 6.4$ & 0.56 \\
\hline
\end{tabular}

a. Data are presented as median (range) (Kruskall-Wallis test to detect differences)

b. Data are presented as mean $\pm S D$ (two-tailed $T$ test to detect differences)

Table 3

Daily basal calcium intake and laboratory tests $(n=149)$

\begin{tabular}{lcccc}
\hline & \multicolumn{3}{c}{ Daily calcium intake } & \\
\cline { 2 - 3 } & Low $(\mathbf{n}=\mathbf{3 8})$ & Normal $(\mathbf{n = 3 9 )}$ & High $(\mathbf{n = 7 2 )}$ & $\mathbf{p ~}$ \\
\hline Hemoglobin $(\mathrm{g} / \mathrm{l})$ & $11.7 \pm 1.2$ & $11.7 \pm 1.0$ & $11.7 \pm 0.9$ & 0.98 \\
Hematocrit $(\%)$ & $34.6 \pm 2.9$ & $34.7 \pm 3.3$ & $34.7 \pm 2.9$ & 0.98 \\
Creatinine $(\mathrm{mg} / \mathrm{dl})$ & $0.72 \pm 0.1$ & $0.83 \pm 01$ & $0.78 \pm 0.2$ & 0.56 \\
Uric acid $(\mathrm{mg} / \mathrm{dl})$ & $3.95 \pm 06$ & $3.50 \pm 03$ & $3.62 \pm 0.7$ & 0.11 \\
\hline
\end{tabular}

Data are presented as mean/SD. Two-tailed t test was used to evaluate differences

Calcium i ntake: Low $<800$ mg/day, Normal: 800-1,200 mg/day High: $>1,200$ mg/day

12.60; NCI median 5.62 mm Hg range 2.04-9.20; and HCI median $0.94 \mathrm{~mm} \mathrm{Hg}$ range $-2.58-4.47 ; \mathrm{p}=0.04$ ). This group had a higher mean blood pressure at birth compared to women with normal and high calcium intake (123.5/73.5 $\pm 15 / 10.2 \mathrm{~mm} \mathrm{Hg}, 116.2 / 65.3 \pm 9.3 / 6.8$ $\mathrm{mm} \mathrm{Hg}$, and 117.2/67.1 $\pm 11.5 / 9.1 \mathrm{~mm} \mathrm{Hg}$, respectively; $\mathrm{p}=0.006)($ Graphics 1, 2). Women with low calcium intake had the highest mean blood pressure at puerperium (LCI $66.31 \pm 8.9 \mathrm{~mm} \mathrm{Hg}$, NCI $65.30 \pm 6.8 \mathrm{~mm} \mathrm{Hg}$, and HCI $61.48 \pm 5.9 \mathrm{~mm} \mathrm{Hg})$ (Graphics 1, 2) $(\mathrm{p}=0.01)$.

During the third trimester, a weak negative correlation between the levels of calcium intake and the increase of the diastolic blood pressure was observed $(r=-0.29,95 \%$ CI $-0.42,-0.13, \mathrm{p}=0.004)$. At puerperium the same 
Table 4

Perinatal outcome of 149 healthy pregnant women

\begin{tabular}{|c|c|}
\hline Pregnancy-induced hypertension ${ }^{a}$ & $11(7.4)$ \\
\hline Gestational hypertension (without proteinuria) ${ }^{\mathbf{a}}$ & $9(6.0)$ \\
\hline Preeclampsia ( $\geq 300 \mathrm{mg} 24 \mathrm{~h} /$ proteinuria) $)^{\mathrm{a}}$ & $2(1.4)$ \\
\hline Gestational diabetes (ACOG criteria) $)^{\mathrm{a}}$ & $15(10.1)$ \\
\hline Urinary infection ( $>10^{5}$ colony in urine culture) $1^{\text {st }}$ trimestera & $9(6.0)$ \\
\hline Urinary infection ( $>10^{5}$ colony in urine culture) $3^{\text {th }}$ trimester $^{\text {a }}$ & $8(5.3)$ \\
\hline Premature rupture of membranes ${ }^{a}$ & $15(10.1)$ \\
\hline Cesarean section ${ }^{\mathrm{a}}$ & $30(20.1)$ \\
\hline Preterm delivery $(<37 \text { weeks of gestational age })^{\mathrm{a}}$ & $9(6.0)$ \\
\hline Arterial umbilical cord blood $\mathrm{pH}^{\mathrm{b}}$ & $7.25 \pm 0.07$ \\
\hline Venous umbilical cord blood $\mathrm{pH}^{\mathrm{b}}$ & $7.31 \pm 0.07$ \\
\hline Arterial $\mathrm{PO}_{2}{ }^{\mathrm{C}}$ & $15(2.0-89.0)$ \\
\hline Birth weight $(g)^{b}$ & $3128 \pm 488$ \\
\hline Low birth weight $(<2.500 \mathrm{~g})^{\mathrm{a}}$ & $9(6.1)$ \\
\hline Small for gestational age $\left(<10^{\text {th }} \text { percentile }\right)^{b}$ & $21(14.0)$ \\
\hline Neonatal APGAR $1^{\text {st }}$ minute ${ }^{b}$ & $8.6 \pm 0.9$ \\
\hline Neonatal APGAR $5^{\text {thb }}$ & $9.8 \pm 0.04$ \\
\hline Hypoglycemia-respiratory distress ${ }^{a}$ & $14(9.4)$ \\
\hline
\end{tabular}

a. Data are presented as n (\%)

c. Data are presented as median (range) b. Data are presented as mean $\pm S D$

ACOG: American College of Obstetricians and Gynecologists criteria (2005) results were observed (calcium intake and the diastolic blood pressure) $(r=-0.25,95 \% \mathrm{CI}-0.39,-0.09, \mathrm{p}=0.01)$.

The pregnant women who further developed pregnancy-induced hypertension had high levels of PTH during pregnancy ( 15 weeks: $27.2 \pm 13 \mathrm{pg} / \mathrm{ml}, 28$ weeks: $27.7 \pm 15.3 \mathrm{pg} / \mathrm{ml}$ ) in comparison to the levels of PTH in pregnant women who remained normotensive $(24.0 \pm 13.3 \mathrm{pg} / \mathrm{ml}, 21.9 \pm 14.8 \mathrm{pg} / \mathrm{ml})(\mathrm{p}=0.01)$.

In multivariate analyses, a significant association was determined among systolic blood pressure increase during pregnancy and low calcium intake and high $\mathrm{PTH}$ levels (regression coefficient $0.53 \mathrm{p}=0.002$ ). At birth, significant association was observed among systolic blood pressure, low calcium intake, and high PTH levels (regression coefficient $0.51 \mathrm{p}=0.001$ ). A total of 32 pregnant women $(21.5 \%)$ had maternal and perinatal morbidity (Table 4). A small incidence of low birthweight was observed $(6.1 \%)$ but the incidence of small for gestational age $\left(<10^{\text {th }}\right.$ percentile) was high $(14 \%)$ (Table 4). Smoking and neonatal weight were negatively correlated $(\mathrm{r}=-0.54, \mathrm{p}=0.01)$. No correlation among calcium intake (low, normal and high), blood pressure levels, and intrauterine growth restriction ${ }^{1}$ (systolic: -0.02 , diastolic -0.04) was observed.

\section{DISCUSSION}

The women included in this prospective study were healthy pregnant women confirmed by clinical parameters, laboratory tests and 24-hour blood pressure Holter Test. To maintain homogeneity of the sample and control for potential biases, women with extreme reproductive age, multiple pregnancy, and borderline high blood pressure, cardiovascular and renal disease were excluded from the study.

The association between calcium intake and parathormone levels and blood pressure levels in non pregnant and pregnant women was described elsewhere ${ }^{2,4,7-9}$. As far it is known this is the first report about the relation between calcium intake and blood pressure levels during pregnancy, birth and puerperium with evaluation of calciotropic hormones and vasoactive mediators. In this study an association between low calcium intake in pregnant women and blood pressure 


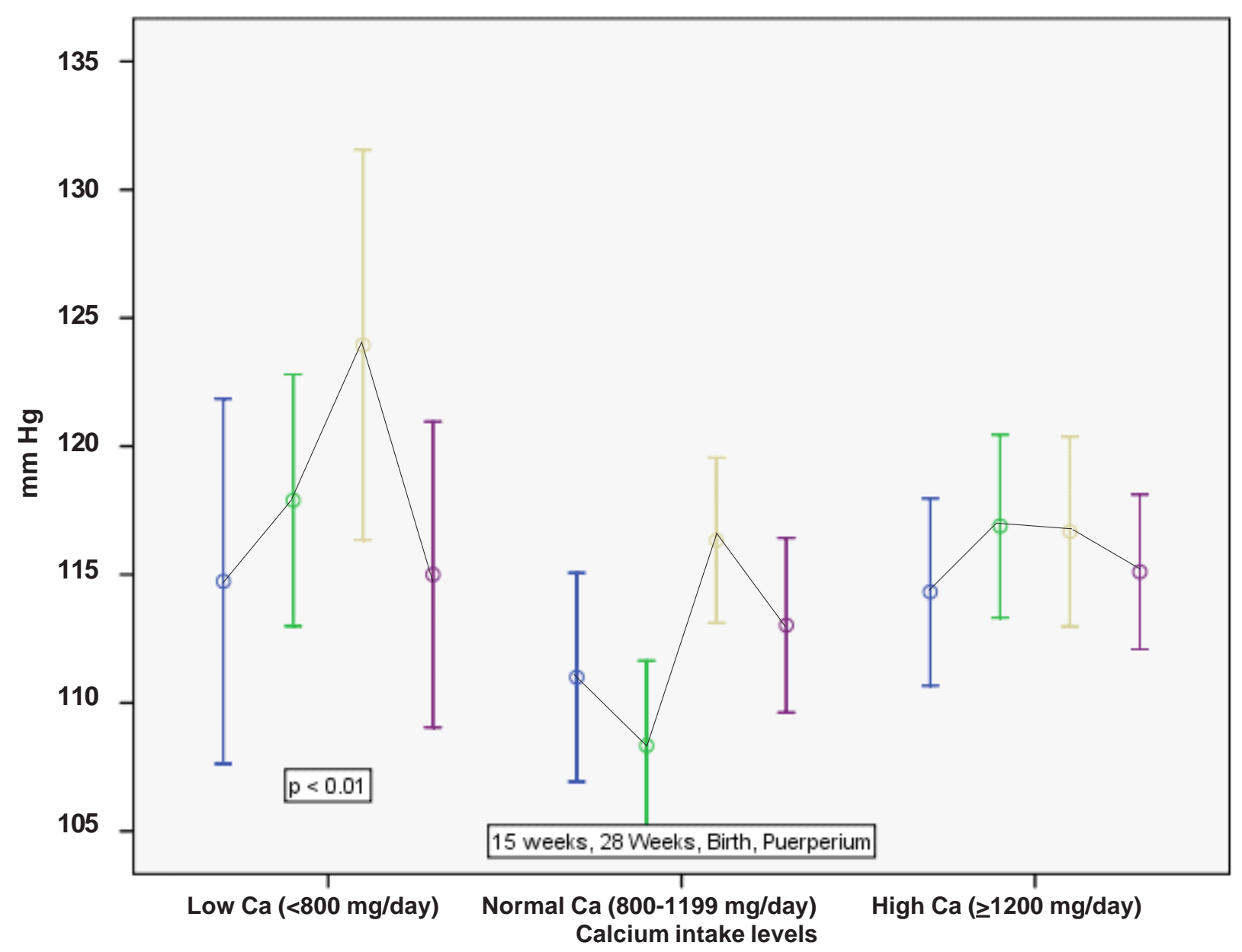

Graphic 1. Systolic blood pressure during the perinatal period by calcium intake

levels during the perinatal period (pregnancy, birth and puerperium) ( $\mathrm{p}=0.01$ ) was observed (Graphics 1, 2).

During pregnancy, there is a great demand for calcium intake to respond to the higher demands caused by the process of fetal bone formation. Furthermore, there is a dilution of the cation due to the expansion of the extracellular fluid volume, and to the normal hypercalciuria of pregnancy, consequent to increased glomerular filtration. Thus, serum-ionized calcium concentrations depend on adequate calcium intake ${ }^{7}$. In this study, calcium nutrient intake, was initially normal and increased during pregnancy according to nutritional habits of women in developed countries. Calcium homeostasis appears to be attained by more efficient intestinal calcium absorption during pregnancy and by renal conservation. PTH seems to play major roles in the adjustment of calcium metabolism ${ }^{15}$. In this study calcium intake was positively correlated to plasma calcium levels indicating that calcium from diet was well absorbed and the creatinine clearance was normal indicating a good renal function. The lack of association between calcium intake and blood pressure in the second trimester was observed in all recruited pregnant women probably associated with good calcium intake observed in $74.6 \%$ of the recruited pregnant women.

At inclusion there were no differences between calcium intake and PTH levels. During the second trimester calcium intake increased with subsequent decrease of PTH, 24 hours calciuria and blood pressure. Calcium is crucial for the production of endothelial vasodilators like prostacyclin and nitric oxide ${ }^{8,16}$. In addition, preeclamptic patients have low levels of serumionized calcium and abnormal levels of calciotropic hormones ${ }^{8}$. In this study PTH levels in pregnant women 


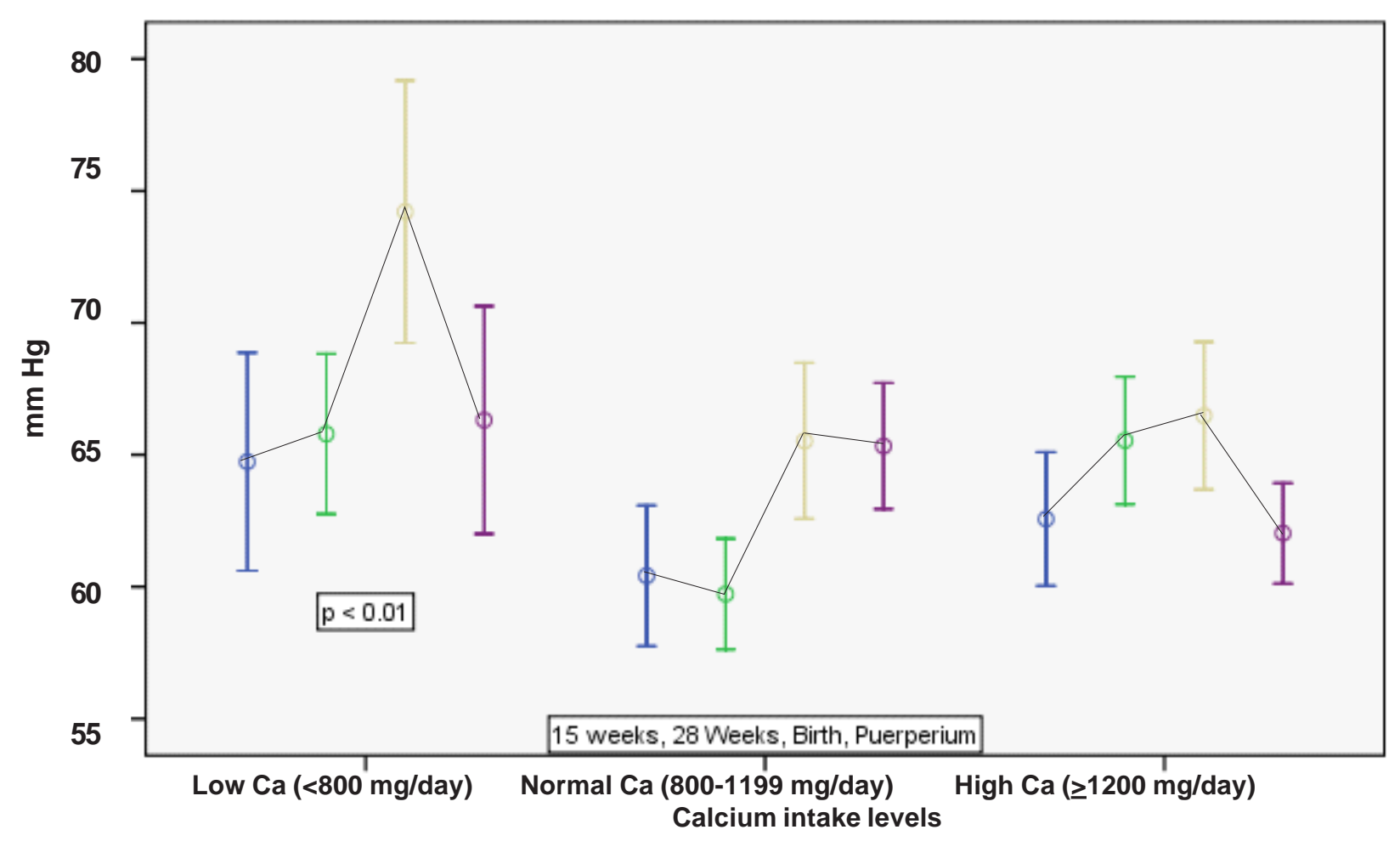

Graphic 2. Diastolic blood pressure during the perinatal period by calcium intake levels

who further developed pregnancy-induced hypertension were high in comparison with women who remained normotensive $(\mathrm{p}=0.01)$ as was described before ${ }^{5}$. This result is consistent with the hypothesis that the PTH is a mediator between the calcium intake and the hypertensive disorders of pregnancy ${ }^{7}$. A high calcium diet enhances vasodilation and reduces blood pressure ${ }^{3,4}$ by suppresion of the parathyroid hypertensive factor ${ }^{5}$ in contrast a low calcium diet enhances vasoconstriction and increases $\mathrm{PTH}^{7}$ as was confirmed in this study. In this study the only assessed vasoactive mediator associated with blood pressure levels and calcium intake was PTH, endothelin and nitric oxide production remained normal.

The incidence of smoke habit and IUGR was high (Table 4). This habit has been associated to IUGR and to low birth weight as confirmed in this and other studies ${ }^{17}$. Recent studies have shown that pregnant women destined to develop preeclampsia have early endothelial dysfunction with higher blood pressurelevels, although within clinical normotensive range ${ }^{18}$. When PTH levels are persistently high ${ }^{5}$, women have high systolic and diastolic blood pressure. In this study, after adjusting for confounding factors, low calcium intake was associated to high PTH levels and large increase of systolic blood pressure during pregnancy. Slightly high levels of blood pressure can alter uterine and placental perfusion and determine fetal growth restriction ${ }^{2}$, a serious condition with implications on the health of newborns ${ }^{19}$. Further large clinical studies are needed to test the clinical implications of the results of this prospective study.

\section{DISCLOSURE OF INTEREST}

The authors have no personal or financial conflict of interest related to this project. Contribution of authorship everyone of 6 authors has collaborated in this study in design (a, c, d, and e) recruitment and follows up of patients (a), recollection and laboratory test analyses (e), re-analyses of data and paper construction (b).

\section{REFERENCES}

1. Nieto A, Matorras R, Serra M, Valenzuela P, Molero J. Multivariate analysis of determinants of fetal growth retardation. 
Eur J Obstet Gynecol Reprod Biol. 1994; 53: 107-13.

2. Jorde R, Sundsfjord J, Haug E, Bonaa KH. Relation between low calcium intake, parathyroid hormone, and blood pressure. Hypertension. 2000; 35: 1154-9.

3. Tranquilli AL, Gianubillo SR. Blood pressure is elevated in normotensive pregnant women with intrauterine growth restriction. Eur J Obstet Gynecol Reprod Biol. 2005; 122: 458.

4. Osborne CG, McTyre RB, Dudek J, Roche KE, Scheuplein R, Silverstein B, et al. Evidence for the relationship of calcium to blood pressure. Nutr Rev. 1996; 54: 365-82.

5. Jolma P, Koobi P, Kalliovalkama J, Saha H, Fan M, Jokihaara $\mathrm{J}$, et al. Treatment of secondary hyperparathiroidism by high calcium diet is associated with enhanced resistance artery relaxation in experimental renal failure. Nephrol Dial Transplant. 2003; 18: 2560-9.

6. Kamycheva E, Sundsfjord J, Jorde R. Serum parathyroid hormone predict coronary heart disease: The Tromso study. Eur J Cardiovasc Prev Rehab. 2004; 11: 69-74.

7. Villar J, Abdel-Hallem H, Merialdi M, Mathai M, Ali MM, Zavaleta N, et al. World Health Organization randomized trial of calcium supplementation among low calcium intake pregnant women. Am J Obstet Gynecol. 2006; 194: 639-49.

8. López-Jaramillo P, González MC, Palmer RMJ, Moncada S. The crucial role of physiological $\mathrm{Ca} 2+$ concentrations in the production of endothelial nitric oxide and the control of vascular tone. Br J Pharmacol. 1990; 101: 489-93.

9. Jespersen B, Randlov A, Abrahamsen J, Fogh-Andersen N, Kanstrup IL. Effects of PTH on blood pressure, renal function and hormones in essential hypertension: the altered pattern of reactivity may counteract raised blood pressure. Am J Hypertens. 1997; 10: 1356-67.
10. López Ongil S, Senchak V, Saura M, Zaragoza C, Ames M, Ballermann BJ, et al. Superoxide regulation of endothelin converting enzyme. J Biol Chem. 2000; 275: 26423-7.

11. Burtis WJ, Brady TG, Orloff JJ, Erzbak JB, Warrel RP Jr, Olson BR, et al. Immunochemical characterization of circulating parathyroid hormone-related protein in patients with humoral hypercalcemia of cancer. N Engl J Med. 1990; 322: 1106-12.

12. Fasano A. Nitric oxide and intestinal water and electrolyte transport: in, out, or both? J Pediatr Gastroenterol Nutr. 2001; 32: 527-8.

13. Bingham SA, Nelson M. Assessment of food consumption and nutrient intake. In: Margetts BM, Nelson M (editors). Desing concepts in nutritional epidemiology. Oxford: Oxford University Press; 1991. p. 153-91.

14. Pickering TG, Shimbo D, Haas D. Ambulatory blood-pressure monitoring. N Engl J Med. 2006; 354: 2368-74.

15. Vargas CL, Donangelo CM, Woodtouse LR, Abrams SA, Spencer EM, King JC. Calcium homeostasis during pregnancy and lactation in Brazilian women with low calcium intakes: A longitudinal study. Am J Clin Nutr. 2004; 80: 417-22.

16. López-Jaramillo P, Guarner F, Moncada S. Effects of calcium and parathyroid hormone on prostacyclin synthesis by vascular tissue. Life Sci. 1987; 40: 983-6.

17. Conde-Agudelo A. Cigarette smoking during pregnancy and risk of preeclampsia: a systematic review. Am JObstet Gynaecol. 1999; 181: 1026-35.

18. García RG, Celedón J, Sierra-Laguado J, Alarcón MA, Luengas $\mathrm{C}$, Silva F, et al. Raised C-reactive protein and impaired flow mediated vasodilation precede the development of preeclampsia. Am J Hypertens. 2007; 20: 98-103.

19. Nieto A, Matorras R, Villar J, Serra M. Neonatal morbidity associated with disproportionate intrauterine growth retardation at term. J Obstet Gynaecol. 1998; 18: 540-3. 